\title{
DETERMINANTS OF ISLAMIC FINANCIAL EXCLUSION IN INDONESIA
}

\author{
Mohammad Mahbubi Ali ${ }^{1}$, Abrista Devi² and Hamzah Bustomi ${ }^{3}$ \\ 1 International Institute of Advanced Islamic Studies, Malaysia, ibnulkhair@gmail.com \\ ${ }^{2}$ Ibnu Khaldun Bogor University, Indonesia, abristasmart@gmail.com \\ ${ }^{3}$ Pakuan University Bogor, Indonesia, hbst007@gmail.com
}

\begin{abstract}
The study aimed to uncover the determinants of Islamic financial exclusion in Indonesia by gathering responses from financially-excluded respondents. A total of 110 respondents were surveyed, representing five provinces: West Java, South Sulawesi, Aceh, East Kalimantan, and North Maluku. The criteria of the selected participants included those who were financially-excluded, those who did not own any Islamic financial products, those without savings or financing, and those with no capital market products. The study employs Confirmatory Factor Analysis (CFA) to identify indicators explaining Islamic financial exclusion determinants in Indonesia. The paper found that location is the key barrier to obtaining financing from and being able to build savings in Islamic banks/Islamic microfinance, while a lack of financial knowledge is identified as the critical barrier when dealing with Islamic capital market products. Overall, most respondents perceived human capital and products and services to be the two most significant determinants of Islamic financial exclusion in Indonesia, followed by infrastructure, policies and regulation, financial literacy, social influence, and religious commitment. The originality of the paper lies in its detailed insight into the perception of being financially excluded on factors leading to Islamic financial exclusion.
\end{abstract}

Keywords: Islamic financial exclusion, Product and services, Human capital, Infrastructure, Policies and regulation.

JEL Classification: D14; G20; G23; G28.

\author{
Article history \\ Received : October 20, 2019 \\ Revised : November 29, 2019 \\ Accepted : March 15, 2020 \\ Available online : May 20, 2020
}

https://doi.org/10.21098/jimf.v6i2.1093 


\section{INTRODUCTION}

\subsection{Background}

Islamic finance, as a new segment in the finance industry, is often viewed as a sector that has the potential to contribute positively to solving financial inclusion issues. This is accurate because the World Bank's 2017 Global Findex Database estimated that about $6 \%$ of unbanked adults in developing countries state that they do not have an account due to religious reasons.

Rosengard and Prasetyantoko (2011) found a paradox in Indonesia's financial sector. Over the past 25 years, Indonesia has been a global leader in microfinance, yet access to microfinance services is relatively low. Moreover, Indonesia's positive economic outlook has bode well during the past decade, but small and medium enterprises have not performed as well. Many SMEs facing a credit crunch due to lack of financial access to formal institutions.

Accordingly, financial exclusion remains a significant problem in Indonesia. The World Bank's 2017 Global Findex Database discovered that only $48.9 \%$ of adults in Indonesia have access to finance, leaving more than half (51.1\%) of them excluded from these services, with no accounts with any financial institutions or even access to a mobile wallet (World Bank, 2017). A survey by Indonesia's Financial Services Authority - Otoritas Jasa Keuangan (OJK) - in 2016 found that Islamic financial inclusion index was $11.1 \%$; this means that out of 100 Indonesian people, only 11 are benefitting from Islamic financial products and services.

Previous studies have identified some barriers to financial access such as channel barriers, information barriers, design product barriers, price barriers (Allen et al. 2014; Beck et al., 2008; Purba, 2016), high minimum balance requirements, complex document requirements (Beck et al., 2008), poor banking infrastructure, reduced level of technological support, high-cost products, lack of suitable product structure in banks, inadequate financial literacy or education, and religious barriers (Allen et al., 2012; Global Findex Survey, 2017; Islam, 2016; Kimutai, 2015; Kostov et al., 2015; Naceur, Barajas \& Massara; 2015; Zins \& Weill, 2016).

Early studies on financial exclusion were conducted by Leyshon and Thrift (1995) in Britain and the United States in response to a financial crisis founded in higher levels of competition and extreme levels of indebtedness. They eventually constructed a financial system infrastructure to overcome this problem. Mylonidis, Chletsos, and Barbagianni (2017) studied financial exclusion in the USA and found that the religious choices and behaviours of an individual might influence people's financial exclusion . In Britain, banking exclusion involves three main factors inappropriate design bank account design for people with limited funds, people's distrust in the banking system, negative perceptions of banking, and experiencing difficulties in managing money without a bank account (Collard, Kempson, \& Whyley, 2001).

A thesis by Warsame (2009) indicates that Islamic finance suggests a solution to financial exclusion in the UK. Nevertheless, strong scepticism about the authenticity, similarity, affordability, acceptability, and accessibility has become the main reason for people's low participation in Sharia-compliant financial products. This finding is supported by previous studies by Naceur, Barajas and Massara (2015) and Sain, Rahman and Khanam (2016) in that Islamic banking 
can reduce the levels of financial exclusion. Muslim communities may have been financially excluded due to their faith and religious beliefs on the prohibition of riba as practiced in conventional banking (Sain, Rahman \& Khanam, 2016; Mylonidis, Chletsos, \& Barbagianni, 2017).

Nevertheless, a cursory review of past studies has discovered that the causes of financial exclusion are complex and sophisticated, thus it is impossible to explain every single factor. In addition, very few studies empirically confirm the effects of religiosity, financial literacy, product suitability, human resources, infrastructure, social influence, and policies on financial exclusion. Some studies have investigated financial barriers as well as financial exclusion in several countries, but similar research has not been carried out in the context of Indonesia. Most literature on the subject is confined to conventional banking exclusion. Therefore, the present study aims to fill the gap in the existing literature by empirically examining the determinants of Islamic financial exclusion in Indonesia, covering a wider area including Islamic banking institutions, Islamic microfinance, and the Islamic capital market. The study surveys financially excluded respondents in relation to their perceived barriers to financial inclusion.

\subsection{Objective}

Against the above background, the research sets out to achieve the determinant factors of Islamic financial exclusion in Indonesia from the perspective of financially excluded respondents. It also attempts to discover appropriate strategies to reduce Islamic financial exclusion in Indonesia.

\section{LITERATURE REVIEW}

\subsection{Financial Exclusion}

Financial exclusion refers to 'a process whereby people encounter difficulties accessing and/or using financial services and products in the mainstream market that are appropriate to their needs and enable them to lead a normal social life in the society in which they belong' (European Commission, 2008). Obaidullah and Latif (2008) define financial exclusion as the exclusion of the poor from the financial system. Meanwhile, Howell (2005) states that financial exclusion is a process that prevents poor and disadvantaged social groups from accessing financial systems. Sinclair (2001) divides the financial exclusion definition into two perspectives the narrow sense and the broader sense. In the narrow sense, financial exclusion is an exclusion from particular sources of credit and other financial services (such as insurance, bill-payment services, and deposit accounts). In a broader sense, financial exclusion refers to factors that shut out the less fortunate from mainstream money services. Nevertheless, to the best of researchers' knowledge, none of the previous studies differentiates between Islamic and conventional financial exclusion. In this study, Islamic financial inclusion is defined as a lack of access to affordable Islamic financial products and services by people on a low income.

Warsame (2009) identifies the criteria of financially-excluded people across two groups of countries (developed and developing). He also highlights some 
measures of financial exclusion based on the majority of the previous studies. These include the long-term unemployed; elderly people with no or few assets; lone parents who cannot work due to family commitments; uneducated people; those who are financially illiterate; ethnic minorities and immigrants for whom the influence of the surrounding community leads to financial exclusion; people living in deprived neighbourhoods with high levels of crime; and people with a history of bad debt whose accounts are usually closed as a result of not repaying or reducing their overdraft facilities, resulting in them finding it difficult to open another account.

Financial exclusion remains a significant global problem. The World Bank's Global Findex Database indicates that approximately 1.7 billion people worldwide remain unbanked; this means they do not have an account at a financial institution or with a mobile money provider. Almost half of these people live in emerging economies, such as Indonesia, India, China, Bangladesh, Pakistan, and Mexico. The database also reveals that most of these unbanked adults are more likely to have gained very little educational. Half of this segment have primary education (or less), while more than one-third have completed high school (post-secondary) education. Another important finding is that those who are active in the labour force are less likely to be financially excluded, while women are more likely to be non-active in the labour force than men (World Bank, 2017).

Indonesia also experiences a significant number of financially-excluded populations. The World Bank's Global Findex Database discovered that only $48.9 \%$ of adults in Indonesia have access to finance, leaving more than half $(51.1 \%)$ excluded from financial services, without an account at any financial institution and without access to a mobile wallet (World Bank, 2017). A survey by the OJK in 2016 found that the Islamic financial inclusion index was $11.1 \%$, which means that of 100 Indonesian people, only 11 are benefitting from Islamic financial products and services.

In response, during recent years, financial inclusion has become the renewed concern of many governments and central banks. The United Nations Development Programme (UNDP) outlined Sustainable Development Goals (SDGs) and endeavoured to improve financial access as an essential enabler for development. National governments across the world have adopted various financial inclusion strategies and measures to improve people's access to financial services. More than 50 countries have already set their targets and strategies to strengthen financial inclusion (Demirguc-Kunt et al., 2015). The Indonesian government has also made significant effort and progress in deepening financial inclusion. The 2012 National Strategy for Financial Inclusion outlines some targets and strategies to provide financial access to all layers of the community. OJK also introduced branchless banking to strengthen financial inclusion, including Layanan Keuangan Tanpa Kantor Dalam Rangka Keuangan Inklusif - Branchless Financial Services for Financial Inclusion (LAKU PANDAI). Similarly, in 2016, Bank Indonesia introduced Layanan Keuangan Digital - Digital Financial Services (LKD) to promote financial inclusion.

Literature related to financial inclusion finds a positive correlation between financial inclusion, inclusive growth, and poverty reduction (Beck et al., 2000, 2004; Demirgüc-Kunt et al., 2008; King et al., 1993; Levine, 2005; WB, 2014). Inclusive 
growth is the process by which poverty and income inequality will diminish and the benefits of growth will spill over into a marginal segment of society (Islam, 2016). Financial inclusion would help the low-income segment to improve their economic situation and, hence, enable them to participate in and benefit from economic activities (Aportela, 1999; Ashraf et al., 2010; Dupas \& Robinson, 2009). This is because as soon as they are financially-included, they can begin to expand their businesses, manage risks, invest in productive sectors, and absorb financial shocks (Islam, 2016).

In contrast, a lack of financial access could lead to liquidity and payment problems, resulting in high fees associated with the use of money orders or checkcashing services (Lusardi, 2010). It might also trigger the poverty trap due to the paucity of opportunity to save when there is a liquidity excess or to borrow during times of hardship (McKillop \& Wilson, 2007; Mohieldin et al., 2011). Warsame (2009) asserts that financial exclusion leads to both financial and social consequences. Financial consequences include the inconvenience and extra costs incurred in a transaction due to the absence of a bank account. Meanwhile, social consequences include feeling like the odd one out and being dependent on others when you have to pay or receive payments to or from the bank. The most extreme negative social consequences include unnecessary dealings with unlicensed lenders, such as loan sharks.

The spirit of financial inclusion corresponds with the philosophical foundation of Islamic finance to promote equal access to financial institutions and fair distributions of wealth (Choudhury, 2001). The International Monetary Fund (2018) acknowledges that 'the growth of Islamic finance presents important opportunities to strengthen financial inclusion, deepen financial markets, and mobilize funding for development by offering new modes of finance and attracting "unbanked" populations that have not participated in the financial system.'

Mohieldin et al. (2011) argue that Islamic finance addresses financial inclusion from two dimensions: firstly, through the promoting of the profit and loss sharing (PLS) concept as an alternative to conventional debt-based financing. The concept can provide Islamic microfinance, funding for small and medium enterprises, and microinsurance to help broaden access to finance. Secondly, through wealth redistribution instruments, such as zakat, sadaqah (alms), waqf (endowment fund), and qardhasan (benevolent loan), which complement PLS instruments.

PLS promotes the financial inclusion agenda because it can offer affordable and fair financial access to those in low-income segments; the imposition of cost and the distribution of profit are based on the actual performance of the business. As a result, the optimum application of PLS will create an equitable distribution of income and wealth among partners or between wealth owners and entrepreneurs, presenting the concept of justice and fairness in financial dealings (Ali, 2018). The risk of transfer underlying the conventional financial system, however, implies asymmetric exposure to economic risk, and does not, therefore, promote economic justice or financial inclusion. It only creates a continuous transfer of wealth from entrepreneurs to wealth owners, irrespective of their economic downturns and business performance (Ali, 2018).

Furthermore, social finance, mandated or otherwise, is an integral part of the Islamic financial system to offer equal opportunities for those in low-income 
segments - the underserved and poor - to access finance 'so that it may not (merely) make a circuit between the wealthy among you' (QS, 59:7). Choudhury (2010) argues that for attaining a heightened level of impact on poverty alleviation, human resource development, income generation, and the sustainability of the Islamic social fund must be combined with other productive financial instruments such as profit-sharing, equity participation, joint ventures, and co-financing. In this regard, Islamic social finance instruments help to improve financial access via various initiatives and strategies, such as microfinance empowerment, poverty alleviation schemes, and educational and entrepreneurship development programmes.

Iqbal (2014) further formulates a more structured and detailed mechanism to strengthen the role of Islamic finance in financial inclusion. Firstly, the instruments of zakah, waqf, and shadaqahare are granted as redistributive pillars and risk sharing instruments through collective support for those who fall below the poverty line (those who are extremely poor). Secondly, the instruments of qardhasan, zakah and waqf are offered as a redistributive pillar and risk sharing for microfinance and microtakaful to the poor segment. Thirdly, the low-income segment is offered hybrid solutions within the redistributive pillar, while risk sharing is provided for MSME financing. Figure 1 depicts the structured mechanism that can enhance the role of Islamic finance in financial inclusion.

Figure 2.1.

Role of Islamic Finance in Financial Inclusion

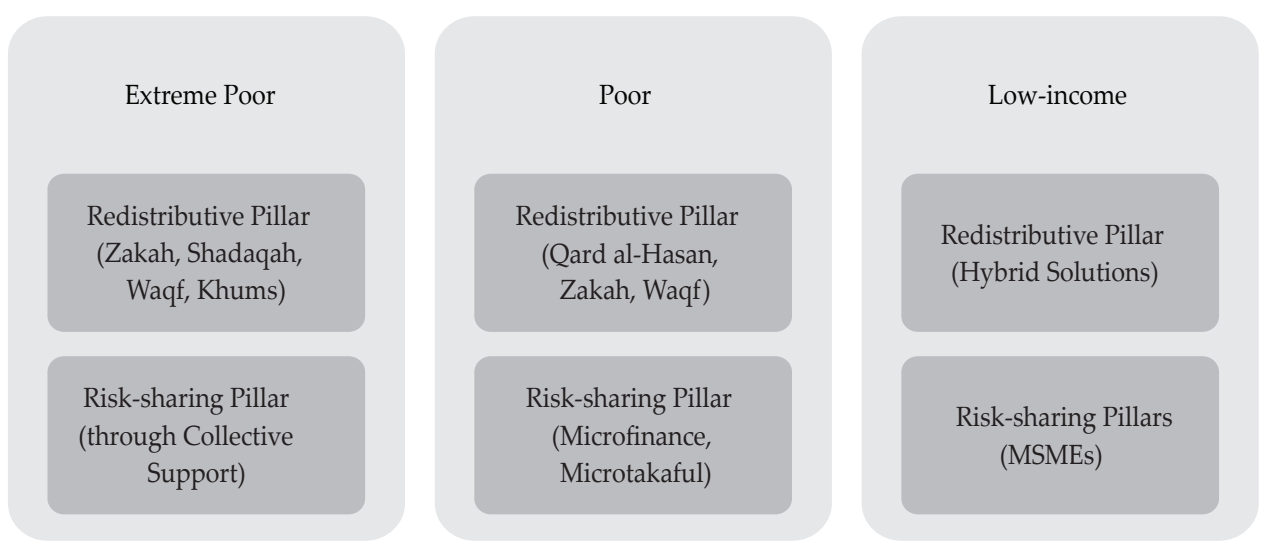

Source: Adopted from Iqbal and Mirakhor (2012 and 2013)

In a similar vein. Jouti (2018) classified the levels of financial inclusion from the perspective of Islamic finance into four categories and their respective strategies as follows:

1. Profile 1: People who do not have a bank account due to religious factors, thus reject all conventional products and services. For this profile, Islamic finance can offer total access to financial services including account ownership, financing, and insurance. This represents the case of pure financial inclusion. 
2. Profile 2: People who have a bank account but are limited to basic services, thus, reject all financing and savings products. Islamic finance should focus on providing access in term of financing and savings to deal with this specific customer profile. This refers to cases of partial financial inclusion.

3. Profile 3: People who use conventional products and services, but prefer Islamic financial services if they are available. For this type of customer, Islamic finance offers a suitable alternative to conventional finance. This profile depicts the case of gradual financial migration.

4. Profile 4: People who use all of the conventional products and services, but are willing to convert these to available Shariah-compliant ones. For this profile, people will immediately switch their conventional financing instruments to Islamic products. It illustrates the case of pure financial migration.

Figure 2.2.

\section{The Levels of Financial Inclusion in Islamic Finance}

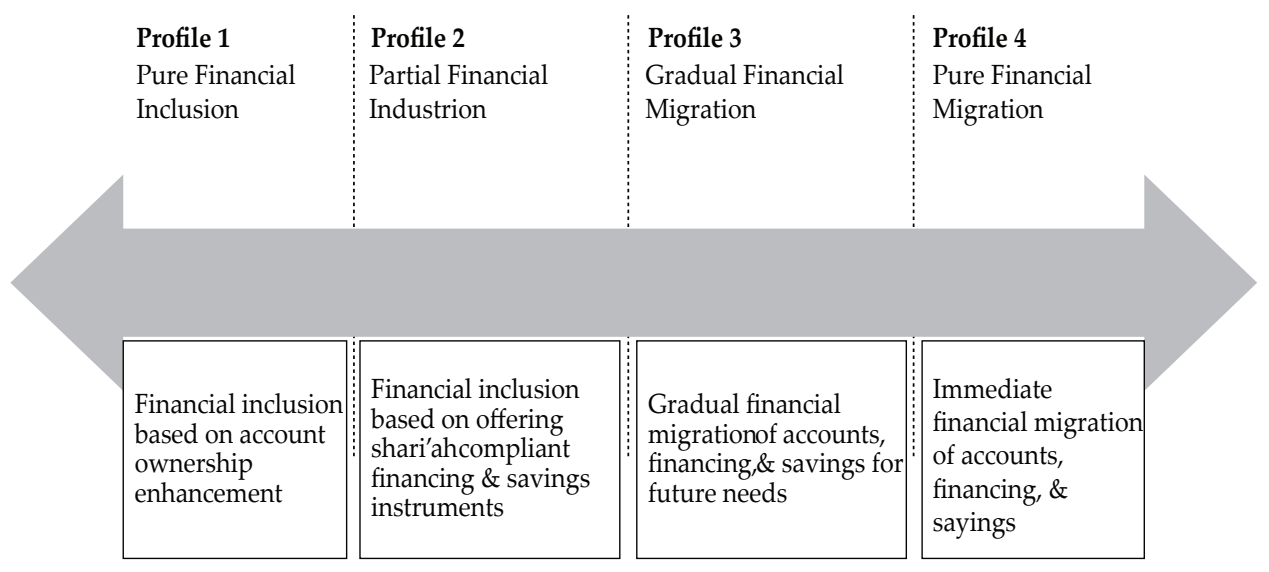

Source: adapted from Jouti (2018), re-drawn by the authors

\subsection{Previous Studies}

There are limited works of literature about Islamic financial exclusion. Previous studies on the subject are mostly confined to financial inclusion or financial exclusion within a conventional finance sphere. Mylonidis, Chletsos, and Barbagianni (2017) surveyed financial exclusion in the USA and discovered that religious choice and behaviour influence people in excluding themselves from financial services. In a similar vein, a thesis by Warsame (2009) determined that Islamic finance is a solution to financial exclusion in the UK. Nevertheless, the strong scepticism about the authenticity, similarity, affordability, acceptability, and accessibility of Islamic finance products has become the main reason for low participation in Sharia-compliant financial products. 
Warsame (2009) also identifies several causes of financial exclusion in both developed and developing countries. These include societal factors, technological advancement factors, cultural and psychological barriers, failure to offer affordable financial products, identification requirements, unfavourable terms and conditions, excessive bank charges, and geographical remoteness.

Carbo, Gardener, and Molyneux (2005) observe that the causes of financial exclusion in developing countries are different to those in developed countries. Their analysis indicates that financial exclusion primarily affects most people living in developing countries, where the issue of poverty and lack of capital resources are paramount.

Kempson and Whyley (1999) discovered five dimensions of financial exclusion: firstly, access exclusion, which stems from branch closures or unfavourable risk assessment. Secondly, condition exclusion; here, individuals are excluded from financial products because they are not designed to suit their particular needs. Thirdly, price exclusion; here, individuals cannot afford financial offerings at the current price. Fourthly, marketing exclusion; for this dimension, individuals are effectively excluded by targeted marketing and sales. Lastly, voluntary nonuse (self-exclusion) is linked to individual preferences and cultural and religious norms.

Simpson and Buckland (2009) empirically investigated consumer barriers to financial credit participation. These include no account/zero balance, credit card refusal, and the use of pawnshops as an alternative. The study also divides financial exclusion into two leading indicators: unbanked and underbanked. The term 'unbanked' refers to the a person's lack of ownership of any bank account, which implies that the household relies heavily on informal financial services for savings, loans, and other payment services. Meanwhile, the term 'underbanked' refers to a person who uses his/her bank account only a few times during a year. Being underbanked also means that a person has limited access to financial services. For example, he can only access a saving account and not a credit/financing account for some reason.

Previous studies identify several barriers to financial access such as channel barriers, information barriers, design product barriers, price barriers (Allen et al. 2012; Beck et al., 2008), high minimum balance requirements, complex document requirements (Beck et al., 2008), poor banking infrastructure, reduced level of technological support, high product costs, lack of banks' suitable product structure, inadequate financial literacy or education, and religious reasons (Allen et al., 2012; Islam, 2016; Zins \& Weill, 2016).

Several studies also investigate the determinants of financial inclusion in conventional finance literature (Allen, 2012; Demirguc-Kunt \& Klapper, 2013; Kimutai, 2015; Zins \& Weill, 2016). Accordingly, there is an important relationship between financial inclusion and different factors, i.e. socio-demographic factors (age, gender, living area, education, marital status, employment, and income), financial literacy, self-efficacy, infrastructure, documents, distance, and the cost of opening an account.

Nevertheless, most previous studies on financial exclusion remain embryonic and are mainly confined to theoretical analysis of banking exclusion within the conventional landscapes of other countries. To the best of the researchers' 
knowledge, no studies have been conducted to empirically examine the issue of financial exclusion in Indonesia in an Islamic finance context. Therefore, the present study aims to empirically discover the determinants of Islamic financial exclusion in Indonesia.

\section{RESEARCH METHODOLOGY}

\subsection{Data}

This study applies quantitative methods - Confirmatory Factor Analysis (CFA) and Second Confirmatory Factor Analysis ( $\left.2{ }^{\text {nd }} \mathrm{CFA}\right)$ - to identify the determinants of Islamic financial exclusion in Indonesia. The primary data for this study were obtained from a field survey in 5 (five) provinces: West Java as a representative of Java Island, South Sulawesi as a representative of Sulawesi Island, Aceh to represent Sumatera, East Kalimantan to represent Kalimantan Island, and North Maluku to represent Maluku. Accordingly, 110 respondents from the five provinces were selected to complete the questionnaire. According to Ascarya and Rahmawati (2018), an appropriate sample size to produce the best estimation parameter of normal data using Maximum Likelihood (ML) is between 100-200 samples. However, Wolf et al. (2013) claim that sample size requirements for simple CFA range between 30 and 450. Sideridis et al. (2014) also states that a sample size of 50-70 would be sufficient for a model involving 4 (four) latent variables. Therefore, the model of this study satisfies all the sample requirements prescribed by the previous studies.

The selection of five provinces, representing five islands of Indonesia, as the sample for this study will obtain a representative result of Islamic financial exclusion with different cultures, characteristics, people, and an Islamic financial inclusion index. The representative provinces are selected using a purposive sampling technique based on the highest financial inclusion indices in each respective island, as released by OJK. The OJK 2016 financial inclusion database report is used as the basis for determining the sample selection because it is the official publication provided by Indonesia's government. The exclusion of Papua considers the small sample number and low financial inclusion index. Furthermore, the random sampling technique was used to obtain the selected respondents.

\subsection{Model Development}

This study endeavours to develop first and second-order factor analysis to address latent variables that underlie indicators in large numbers. Second-order factor analysis is used to identify latent variables that are more closely related to the theory or concept than the indicators. In this study, we assume that there are more general and abstract latent variables that might underlie or influence 'level one' or 'first-order' latent variables. Latent variables that are strictly related to the observed variables may be affected by those that are not directly associated with the observed variables. The latter is known as 'higher-order factor analysis'. Higherorder factor analysis is more informative than first order (Anderson \& Gerbing, 1984). Therefore, this study employs the hybrid higher-order confirmatory analysis model. 
Theoretically, the CFA model of this study is divided into two: firstly, financial exclusion determinants, which originate from demand-side factors, and secondly financial exclusion determinants, which arise from supply-side factors. However, here, both factors will be computed into one hybrid model to obtain comprehensive information ranging from the most critical factors to the less critical factors. The CFA model comprises of 9 (nine) latent variables, in which the $1^{\text {st }}$ CFA level will consist of 8 (eight) latent variables (four latent variables for demand-side factors and four for supply-side factors). Latent variables for demand-side factors include socioeconomics (SE), financial literacy (FL), religious commitment (RC), and social influence (SI), while latent variables for supply-side factors include infrastructure (I), product and services (PS), human capital (HC), and policies and regulations (PR). Meanwhile, the $2^{\text {nd }}$ level of the CFA comprises one latent variable, namely financial exclusion (FE). Table 3.1 summarises the operational definition of all of the variables in this study.

Table 3.1.

\section{Operational Definition}

\begin{tabular}{|c|c|}
\hline $\begin{array}{l}\text { DEMAND SIDE } \\
\text { Factors affecting the dec }\end{array}$ & ncome communities to use Islamic financial product and services \\
\hline $\begin{array}{l}\text { Socioeconomic (SE) } \\
\text { Differences between grot }\end{array}$ & caused mainly by their financial situation \\
\hline Gender & $\begin{array}{l}\text { Whether the customer is male or female (Allen et al., 2012; Clamara } \\
\text { \& Tuesta, 2014; Gallup World Poll, 2012; Ogunsakin \& Olumide, } \\
\text { 2017) }\end{array}$ \\
\hline Age & $\begin{array}{l}\text { Age and age squared are both in years (Allen et al., 2012; Clamara \& } \\
\text { Tuesta, 2014; Gallup World Poll, 2012; Ogunsakin \& Olumide, 2017) }\end{array}$ \\
\hline Living Area & $\begin{array}{l}\text { Whether those in the low-income segment live in rural areas or } \\
\text { inurban areas (Allen et al., 2012; Clamara \& Tuesta, 2014; Gallup } \\
\text { World Poll, 2012; Naceur, Barajas \& Massara, 2015) }\end{array}$ \\
\hline Marital Status & $\begin{array}{l}\text { Whether the customer is single, married or divorced (Allen et al., } \\
\text { 2012; Clamara \& Tuesta, 2014; Gallup World Poll, 2012; Ogunsakin \& } \\
\text { Olumide, 2017) }\end{array}$ \\
\hline Education & $\begin{array}{l}\text { The level of formal education of those on a low-income ( Allen et al., } \\
\text { 2012; Clamara \& Tuesta, 2014; Gallup World Poll, 2012; Ogunsakin \& } \\
\text { Olumide, 2017) }\end{array}$ \\
\hline Economic Status & $\begin{array}{l}\text { Economic status contains information of monthly base salary of } \\
\text { individual income as well as employment status (Allen et al., 2012; } \\
\text { Clamara \& Tuesta, 2014; Gallup World Poll, 2012; Ogunsakin \& } \\
\text { Olumide, 2017) }\end{array}$ \\
\hline $\begin{array}{l}\text { Financial Literacy (FL) } \\
\text { The possession of the set } \\
\text { with all of their financia }\end{array}$ & knowledge that allows an individual to make informed and effective decisions \\
\hline Financial Knowledge & $\begin{array}{l}\text { Financial awareness and understanding about the financial concepts } \\
\text { and procedures as well as the use of this understanding to solve } \\
\text { financial problems (Bassir et al., 2015; GPFI, 2016) }\end{array}$ \\
\hline Financial Education & $\begin{array}{l}\text { A process of acquiring knowledge, both formally and informally, } \\
\text { related to finance (Jumpstart, 2006; Kimutai, 2015) }\end{array}$ \\
\hline Financial Behaviour & $\begin{array}{l}\text { The capability to capture the understanding of the overall impact of } \\
\text { financial decisions on one's (i.e. person, family, community, country) } \\
\text { circumstances (GPFI, 2016). }\end{array}$ \\
\hline
\end{tabular}


Table 3.1.

Operational Definition (Continued)

\begin{tabular}{ll}
\hline Fintech Awareness & $\begin{array}{l}\text { People cognizance to embrace and use new financial technology } \\
\text { instruments for accomplishing their financial goals }\end{array}$ \\
\hline Financial Self-Efficacy & Individuals' perceived ability to manage their finance (Lapp, 2010) \\
\hline Use of Media & $\begin{array}{l}\text { Frequency of mass media use, social media, internet, and mobile } \\
\text { media/mobile applications to obtain financial information (Kimutai, } \\
\text { 2015) }\end{array}$ \\
\hline $\begin{array}{l}\text { Religious Commitment (RC) } \\
\text { The extent a person decides to use or not to use certain financial products and services based on his or her religious } \\
\text { consideration }\end{array}$ & $\begin{array}{l}\text { A strong intention and dedication to perform religious obligation } \\
\text { such as prayers, zakat, and fasting }\end{array}$ \\
\hline $\begin{array}{l}\text { Commitment to worship } \\
\text { (ibadah) }\end{array}$ & $\begin{array}{l}\text { A strong faith and fear of God's punishment, and thus a person does } \\
\text { not transgress His commands }\end{array}$ \\
\hline Fear of divine punishment & $\begin{array}{l}\text { The extent to which households/enterprises believe that interest- } \\
\text { based institution is riba, which is unequivocally prohibited in Islam } \\
\text { (Brekke, 2018) }\end{array}$ \\
\hline $\begin{array}{l}\text { Perception on interest-based } \\
\text { transaction }\end{array}$ & $\begin{array}{l}\text { A strong faith and intention of households/enterprises to use } \\
\text { interest-free transaction }\end{array}$ \\
\hline $\begin{array}{l}\text { Commitment to use interest free } \\
\text { transaction }\end{array}$ & $\begin{array}{l}\text { The difficulty faced by households/enterprises in finding interest-free } \\
\text { transaction (Brekke, 2018) }\end{array}$ \\
\hline $\begin{array}{l}\text { Barrier in finding interest-free } \\
\text { transaction }\end{array}$ & $\begin{array}{l}\text { Self-identified association of a person with a religious group, such } \\
\text { as Nahdlatul Ulama (NU) and Muhammadiyah, or Islamic schools of } \\
\text { thought (mazhab) }\end{array}$ \\
\hline Religious Affiliation &
\end{tabular}

Social Influence (SI)

The perceived social pressure to use or not to use an interest-free transaction from any Islamic financial institutions (IFI)

\begin{tabular}{ll}
\hline Family Influence & $\begin{array}{l}\text { The influence or pressure from known sources (family) to use an } \\
\text { interest-free transaction from IFIs (Fox et al., 2000; Lin, 2007; Ng and } \\
\text { Rahim, 2005; Rouibah, 2008; Shim et al., 2010; Xiao et al., 2007) }\end{array}$ \\
\hline Friends/colleague Influence & $\begin{array}{l}\text { The influence of a [close] person on an individual's behavior to an } \\
\text { interest-free transaction from IFIs (Agarwal et al., 2009; Fox et al., } \\
\text { 2000; Shim et al., 2010; Xiao et al., 2007) }\end{array}$ \\
\hline Media Influence & $\begin{array}{l}\text { The influence or pressure from the mass and/or social media to use } \\
\text { an interest-free transaction in IFIs (Bhattacherjee, 2000; Fox et al., } \\
\text { 2000; Ng \& Rahim, 2005; Rogers, 2003; Shim et al., 2010; Xiao et al., } \\
\text { 2007) }\end{array}$ \\
\hline Informal leader Influence & $\begin{array}{l}\text { The influence or pressure from an informal leader, i.e. ustadz and } \\
\text { kyai, to use an interest-free transaction from IFIs (Fox et al., 2000; } \\
\text { Shim et al., 2010; Xiao et al., 2007) }\end{array}$ \\
\hline Community Influence & $\begin{array}{l}\text { The influence or pressure from a cohort/community to be involved in } \\
\text { interest-free transactions }\end{array}$ \\
\hline Culture Influence & $\begin{array}{l}\text { The perceived cultural influence that has an impact on the behaviour } \\
\text { of consumption, saving, and the investment decision making of } \\
\text { individuals }\end{array}$ \\
\hline $\begin{array}{l}\text { SUPPLY SIDE } \\
\text { Factors affecting the decision and accessibility of IFIs in providing financial access to low-income communities }\end{array}$ \\
\hline $\begin{array}{l}\text { Infrastructure (I) } \\
\text { The basic physical and organisational structures and facilities needed for the operation of IFIs }\end{array}$ \\
\hline Location & $\begin{array}{l}\text { A particular place in which an IFI operates (Kimutai, 2015; World } \\
\text { Bank Group, 2012; Ogunsakin \& Olumide, 2017) }\end{array}$ \\
\hline
\end{tabular}




\section{Table 3.1. \\ Operational Definition (Continued)}

\begin{tabular}{ll}
\hline Distance & $\begin{array}{l}\text { The distance between one outlet/branch/outlet services and the next } \\
\text { (Kimutai, 2015; Ogunsakin \& Olumide, 2017; World Bank Group, } \\
\text { 2012) }\end{array}$ \\
\hline Distribution Channel & $\begin{array}{l}\text { A chain of delivery channels that enhances the outreach and } \\
\text { accessibility of IFI products and services, particularly for the low- } \\
\text { income communities (BNM, 2015; Kimutai, 2015) }\end{array}$ \\
\hline Mobile Infrastructure & $\begin{array}{l}\text { The use of cellular technology for various financial services, such as } \\
\text { payment, transfer, and placement (Abimbola et al., 2018; Kimutai, } \\
\text { 2015) }\end{array}$ \\
\hline Network Connectivity & $\begin{array}{l}\text { A system and communication link between IFIs and their agent } \\
\text { channel or between IFIs and customers during transactions (Kimutai, } \\
\text { 2015) }\end{array}$ \\
\hline FinTech Readiness & $\begin{array}{l}\text { The readiness of technology devices, vendors, and regulations to } \\
\text { facilitate and accelerate the financial services transformation through } \\
\text { innovative platforms }\end{array}$ \\
\hline
\end{tabular}

Product \& Services (PS)

Financial products and services that meet market needs and capacities

Product-fit The ability of financial products and services to satisfy the needs of customers (World Bank Group, 2012) and ensure Shariah compliance requirements are met

Transparency The ability of financial product and services to provide clear, honest, and open information (World Bank Group, 2012)

\begin{tabular}{ll}
\hline Safety & $\begin{array}{l}\text { The ability of financial product and services to ensure safe and } \\
\text { secure transactions (World Bank Group, 2012) }\end{array}$ \\
\hline Transaction Cost & $\begin{array}{l}\text { The quantum of fees and charges imposed by IFIs in providing } \\
\text { financial products and services }\end{array}$ \\
\hline Documentation Requirements & $\begin{array}{l}\text { A specific set of documents requested by financial institutions as a } \\
\text { part of know your customer (KYC) processes. The documents may } \\
\text { include identity certificates (KTP), proof of employment, and salary } \\
\text { slips }\end{array}$ \\
\hline Collateral & A security required by IFIs to secure repayment of financing \\
\hline
\end{tabular}

Human Capital (HC)

The collective skills, knowledge, or other intangible assets of IFI employees that can be used to create economic value for individuals, organisations, or their communities

\begin{tabular}{ll}
\hline Education Background & $\begin{array}{l}\text { The background education of IFIs employees as to whether they are } \\
\text { equipped with Islamic finance-related courses. }\end{array}$ \\
\hline Understanding and Knowledge & $\begin{array}{l}\text { The level of understanding and knowledge of IFI employees about } \\
\text { the concept and practices of Islamic finance }\end{array}$ \\
\hline Social Awareness & $\begin{array}{l}\text { The ability of IFI employees to understand, and respond to, the } \\
\text { needs of society and communities }\end{array}$ \\
\hline Employment Background & $\begin{array}{l}\text { The previous working experience of IFIs employees to determine } \\
\text { whether they have experience in Islamic financial institutions or } \\
\text { conventional financial institutions }\end{array}$ \\
\hline KPI Targeting & $\begin{array}{l}\text { A measurable value to employees that indicates how effectively IFIs } \\
\text { can achieve their business goals }\end{array}$ \\
\hline Risk taking Behaviour & The tendency of IFIs employees to engage in risk-taking activities \\
\hline $\begin{array}{l}\text { Policies \& Regulation (PR) } \\
\text { The directive or statute enforced by law, which is legally binding }\end{array}$ \\
\hline
\end{tabular}


Table 3.1.

Operational Definition (Continued)

\begin{tabular}{ll}
\hline Literacy Regulation & $\begin{array}{l}\text { The regulators' framework for financial literacy to improve financial } \\
\text { access for low-income communities }\end{array}$ \\
\hline Incentives and Initiatives & $\begin{array}{l}\text { A scheme offered by regulators to promote and encourage financial } \\
\text { access of low-income communities during a defined period of time }\end{array}$ \\
\hline FinTech Regulation & $\begin{array}{l}\text { The regulators' framework on Fintech business such as start-up, } \\
\text { crowdfunding and blockchain }\end{array}$ \\
\hline Consumer Protection & Any guidelines and regulations governing consumer protection \\
\hline Distribution Policy Regulation & $\begin{array}{l}\text { A regulation that outlines how IFI products and services can be } \\
\text { accessed by customers }\end{array}$ \\
\hline Data Infrastructure & $\begin{array}{l}\text { The laws and government regulations on data infrastructure } \\
\text { that cover consumer identification data, data sharing and data } \\
\text { consumption }\end{array}$ \\
\hline
\end{tabular}

Figure 3.1.

2nd CFA Model of Determinants of Islamic Financial Exclusion in Indonesia

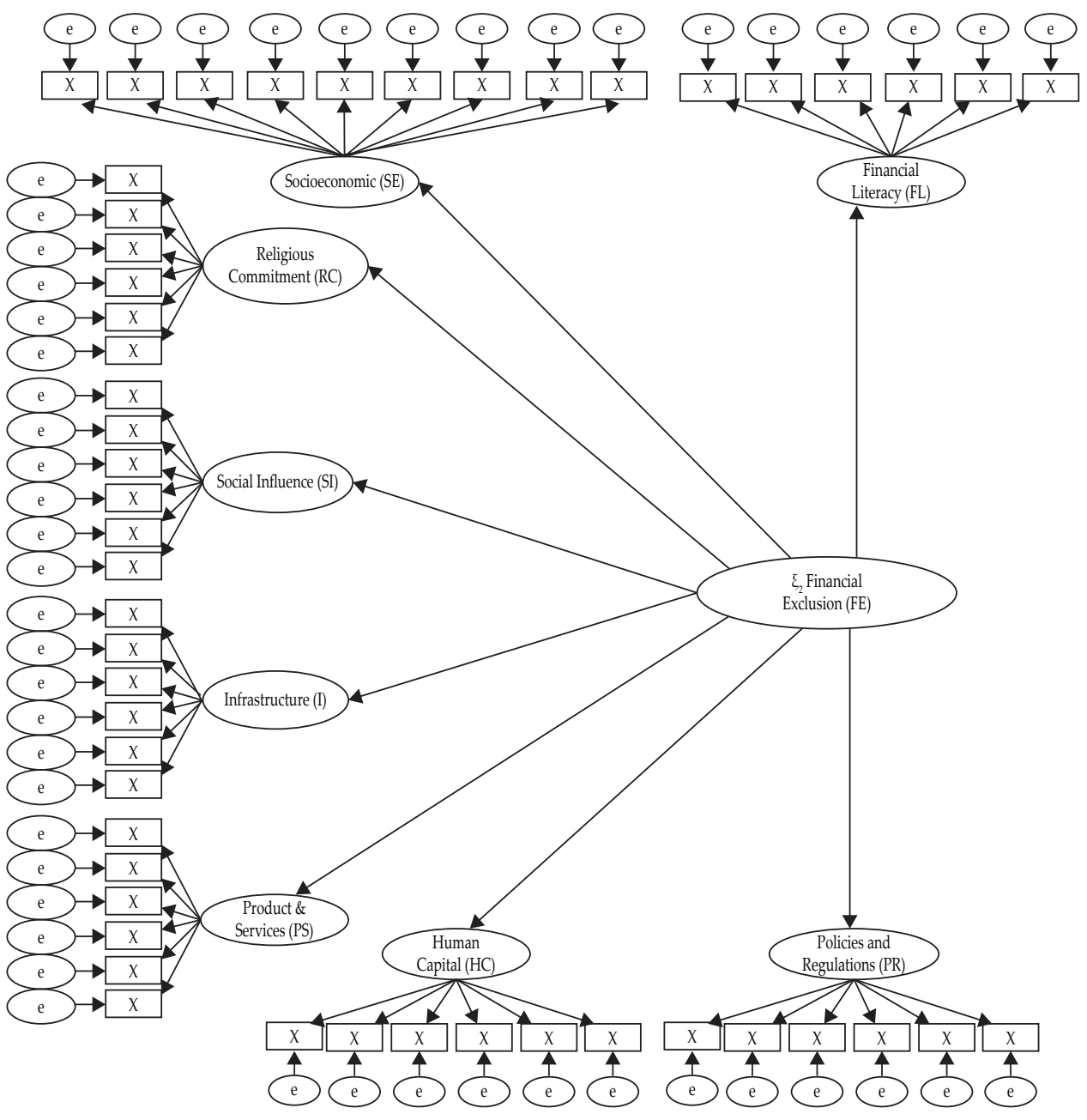




\subsection{Method}

The CFA method is employed to obtain the informative results of this study. Ascarya and Rahmawati (2018) and Suhr (2006) review the concept of 'Confirmatory Factor Analysis' (CFA) or 'Exploratory Factor Analysis' (EFA) to describe the measurement of indicator variables or measured variables reflecting, measuring or estimating their respective latent variables. The proposed variables are built upon and selected based on their underlying theories. CFA is a form of Structural Equation Modelling (SEM) with a specific measurement function. CFA provides information about the relationship between observed variables and their latent variables. CFA has also become the most commonly used statistical tool in applied research (Brown, 2006). In this study, CFA will be used to uncover the most and least critical indicators of Islamic financial exclusion determinants in Indonesia.

CFA provides relationship hypothesis testing between the observed variables and their underlying latent variable(s). The use of CFA could be influenced through the testing of the research hypothesis, sufficient sample size, measurement instruments, multivariate normality, parameter identification, outliers, missing data, and interpretation of model fit indices (Schumacker \& Lomax, 1996; Suhr, 2006). CFA also comprises the following research steps:

1. A review of the relevant theory and research literature to support model specification

2. Model specification (e.g. diagram, equations)

3. Model identifications

4. Data collection

5. Preliminary descriptive statistical analysis

6. The model's parameter estimation

7. Model fit assessment

8. Results interpretation

\section{RESULTS AND ANALYSIS}

\subsection{Results}

\subsubsection{Respondent Profile}

The primary data was collected using a questionnaire and responses were gathered from 110 financially-excluded respondents. The criteria of financial exclusion were those who had no Islamic financial products from any Islamic financial institutions, including banks, microfinance, and the capital market.

The first category describes the information regarding the respondents' gender. Of the 110 respondents, $51.68 \%$ were male, while female respondents accounted for $48.32 \%$. Regarding age, the survey observed the following: of the respondents, $1.11 \%$ were below the age of 21, 48.01\% of respondents were aged between 21 and 30 , and $29.48 \%$ of respondents were aged between 31 and 40 . Respondents aged between 41 and 50 accounted for $12.55 \%$. Respondents aged between 51 and 60 represented only $6.27 \%$. Those aged between 61 and 17 represented $2.58 \%$ of the total number of respondents.

Regarding level of employment, respondents were dominated by active employees at $69.21 \%$. Of those, $17.27 \%$ were entrepreneurs and $5.77 \%$ were registered as both employees and entrepreneurs. Unemployed respondents 
were the minority in this study at 7.75\%. From the results exhibited in Table 4.1, it is clear that the highest number of respondents' regarding education level was $40.63 \%$; these respondents had graduated from senior high school. Of the respondents, $31.22 \%$ had a bachelor's degree, $12.14 \%$ had gained a diploma, and $3.99 \%$ graduated from elementary school. Only $0.99 \%$ of the respondents were uneducated. Those with master's and doctoral degrees represented $2.79 \%$ and $2.26 \%$ of the total respondents, respectively.

The next description is the respondents' profiles based on their marital status. Table 4.1 shows that $54.64 \%$ of respondents were married, $43.20 \%$ of respondents were single/unmarried, and $1.16 \%$ of respondents were divorced. Table 4.1 also summarises the respondents' profiles.

Table 4.1.

The Structure of Respondents by Demography

\begin{tabular}{lccc}
\hline Gender & Percentage & Education & Percentage \\
\hline Female & 48.32 & Uneducated & 0.99 \\
Male & 51.68 & Elementary & 3.99 \\
\hline Age & & Middle/Junior & 6.02 \\
\hline$<21$ years & 1.11 & Senior & 40.63 \\
$21-30$ years & 48.01 & Diploma & 12.14 \\
$31-40$ years & 29.48 & Bachelor & 31.22 \\
$41-50$ years & 12.55 & Master & 2.79 \\
$51-60$ years & 6.27 & Doctoral & 2.26 \\
$61-70$ years & 2.58 & & \\
$>71$ years & 0.00 & Marital Status \\
Occupation & 17.27 & Unmarried & \\
\hline Entrepreneur & 69.21 & Married & 43.20 \\
Employee & 5.77 & Divorced & 54.64 \\
Entrepreneur and Employee & 7.75 & Widow/Widower left due to & 0.16 \\
Unemployed & \multicolumn{4}{c}{ death } \\
\hline
\end{tabular}

As indicated earlier, the survey was conducted in 5 (five) provinces, namely West Java as a representative of Java Island, South Sulawesi as a representative of Sulawesi Island, Aceh to represent Sumatera, East Kalimantan to represent Kalimantan Island, and North Maluku to represent Maluku. Most respondents were from West Java (78.18\%), 10.00\% of respondents were from South Sulawesi, $6.36 \%$ were from Aceh, and 2.73\% were from North Maluku and East Kalimantan, respectively. Figure 4.1 details the information about the respondents' distribution in each province: 
Figure 4.1.

The Structure of Respondents by Living Area

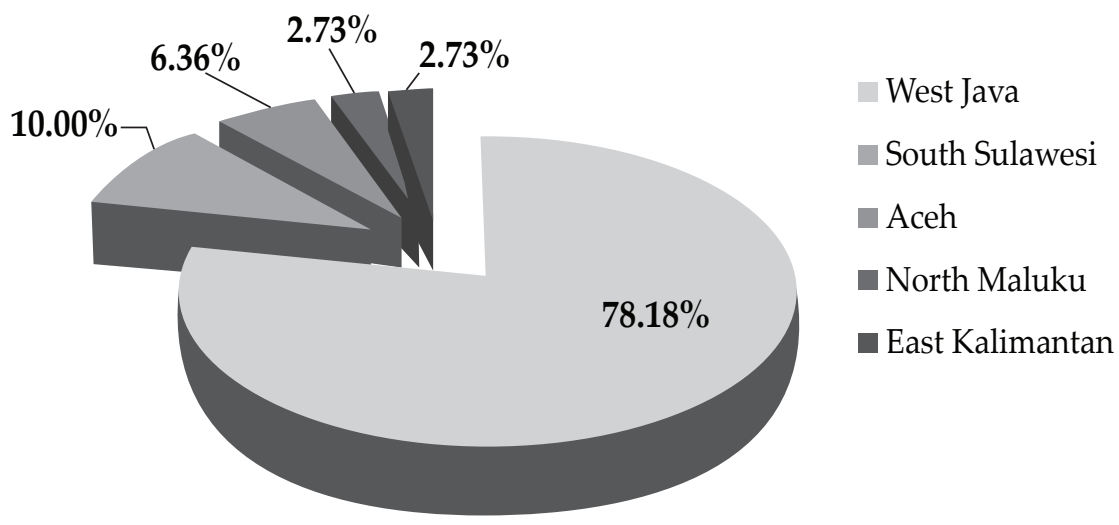

\subsubsection{Obstacles of Account Ownership and Financing in Indonesia}

This section presents the survey findings regarding the barriers faced by financially-excluded respondents when trying to access IFI products and services. The results show that most respondents believe that location is the main barrier to obtain financing in IFIs $(42.73 \%)$, followed by complicated administration procedures $(14.85 \%)$, lack of proper financial reports (13.56), lack of required documentation $(14.55 \%)$, expensive administrative costs $(9.09 \%)$, and morecostly PLS financing cost $(5.17 \%)$, respectively. This finding is consistent with the previous study regarding the three dimensions of the Islamic financial inclusion index in that availability (distance from accessing Islamic banking services) is the main factor for financial exclusion in Indonesia (Umar, 2017). This is true because 1 (one) branch is expected to serve up to 100,000 people. The survey also identifies two other financial exclusion factors - the absence of financing people's needs and the lack of socialisation in relation to Islamic financing products and processes.

The second part of Figure 4.2 indicates that the location of Islamic banks/Islamic microfinance is the most crucial barrier to opening a banking account $(57.27 \%)$, followed by complicated administration procedures $(16.36 \%)$, lack of required documents $(8.81 \%)$, lack of trust in IFIs $(8.18 \%)$, and expensive administrative costs $(9.09 \%)$, respectively. Other factors include the following: 1$)$ they have a joint account with their spouse; 2) they have a conventional account; 3 ) there is a lack of information about Islamic financial products and services; and 4) there is less technological competitiveness. 
Figure 4.2.

\section{Barriers to Financial Access in Islamic Banks and Islamic Microfinance}

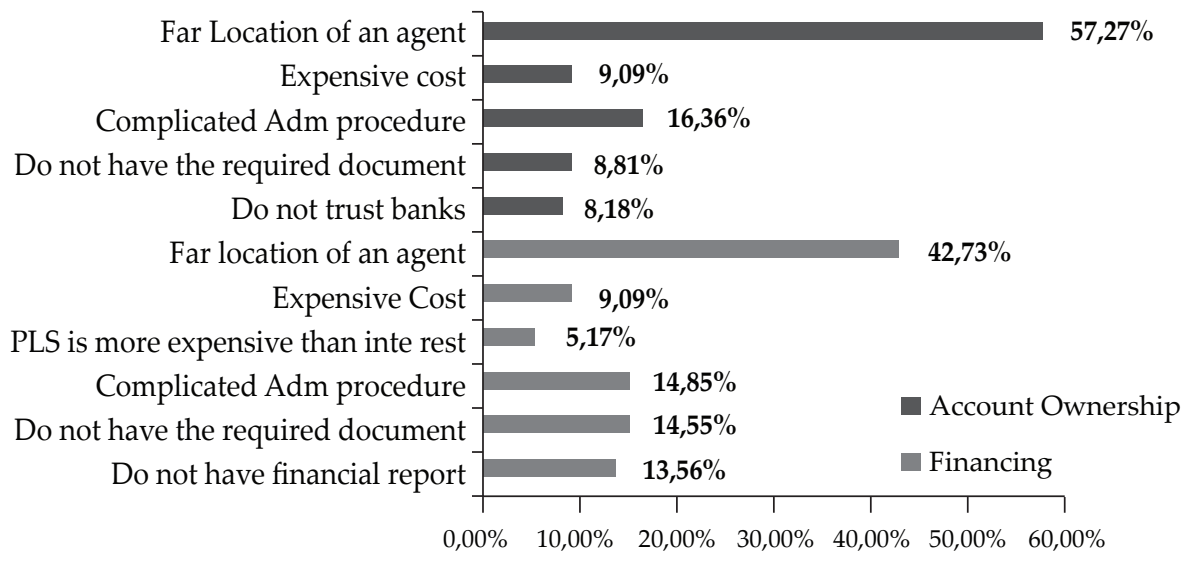

Regarding barriers to financial inclusion in the Islamic capital market, the survey discovered that lack of knowledge about the Islamic capital market is the most significant barrier to opening an Islamic capital market account at $20.91 \%$, followed by lack of information about Islamic capital market products $(20.00 \%)$, lack of knowledge on technology in the Islamic capital market $(14.55 \%)$, absence of interest to invest $(14.55 \%)$, high risk (10.91\%), distance from an agent $(9.09 \%)$, unaffordable minimum investment placement (2.80\%), complicated administration procedures $(1.71 \%)$, lack of trust in the agent $(1.56 \%)$, not having the required documents $(1.56 \%)$, expensive brokerage fees $(1.40 \%)$, and high cost of opening an account (1.25\%), respectively. Other reasons include the following: 1) already have a conventional account in the capital market; 2) prefer to invest in real businesses; 3) lack of suitable products; and 4) it is perceived as less-profitable.

Figure 4.3.

\section{Obstacles to Account Ownership in the Islamic Capital Market}

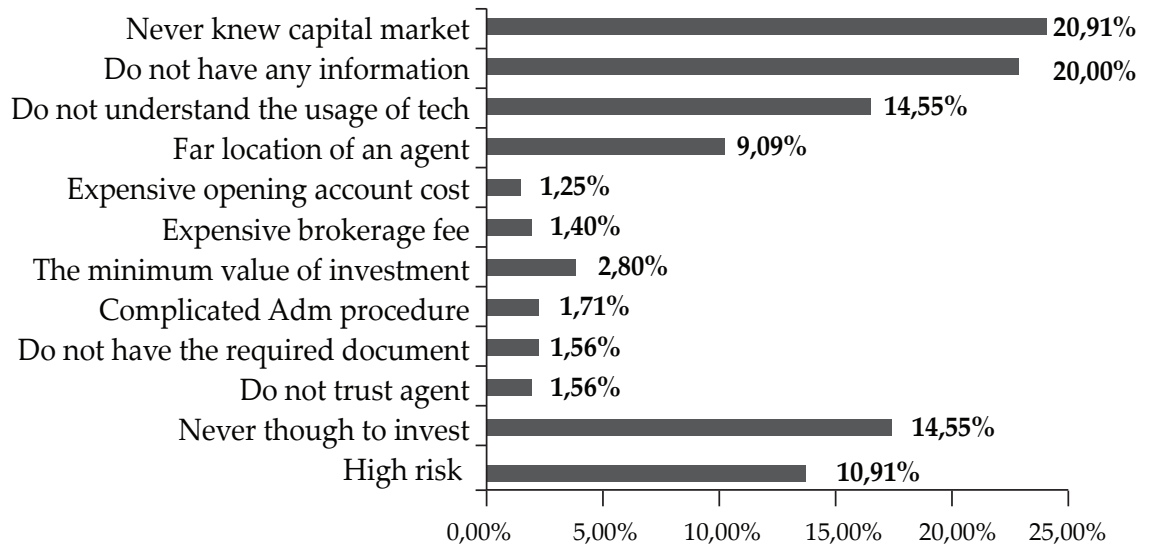


The survey also discovered that financially-excluded customers are further divided into two types: voluntary self-exclusion and involuntary exclusion. Those in the voluntary self-exclusion group are people who voluntarily exclude themselves from Islamic financial transactions and opt out of using Islamic financial products or services. Some reasons underpinning this situation include the following: firstly, they do not urgently need to use Islamic financial services. Most of them keep their money at home and do not consider a bank as an option for saving or borrowing. Some respondents argued that financial institutions belong to middle-upper class society. Unless they have to use financial products, they prefer to use traditional methods of wealth management. Secondly, they are not interested in dealing with Islamic financial institutions. Some voluntary selfexcluded respondents believe there are no significant differences between Islamic and conventional financial products. Resultantly, they maintain their existing conventional accounts rather than to shift to IFIs.

Those who are involuntarily excluded include people who are interested in participating in Islamic financial products and services, but they encounter barriers to gaining financial access. The study determined at least five main reasons why involuntary excluded respondents find it difficult to access Islamic financial products and services, including inadequate knowledge of Islamic financial institutions' products and information technology, location barriers, complicated administrative procedures, lack of required documents, and price/ product features. This finding confirms the study by Allen et al. (2012) who state that unbanked people have their own reasons for not opening a banking account. These include religion, lack of trust in financial institutions, lack of necessary documentation, distance barriers, expense, joint accounts, and insufficient money. Figure 4.4 summarises these barriers to Islamic financial inclusion.

Figure 4.4.

\section{Barriers to Islamic Financial Inclusion}

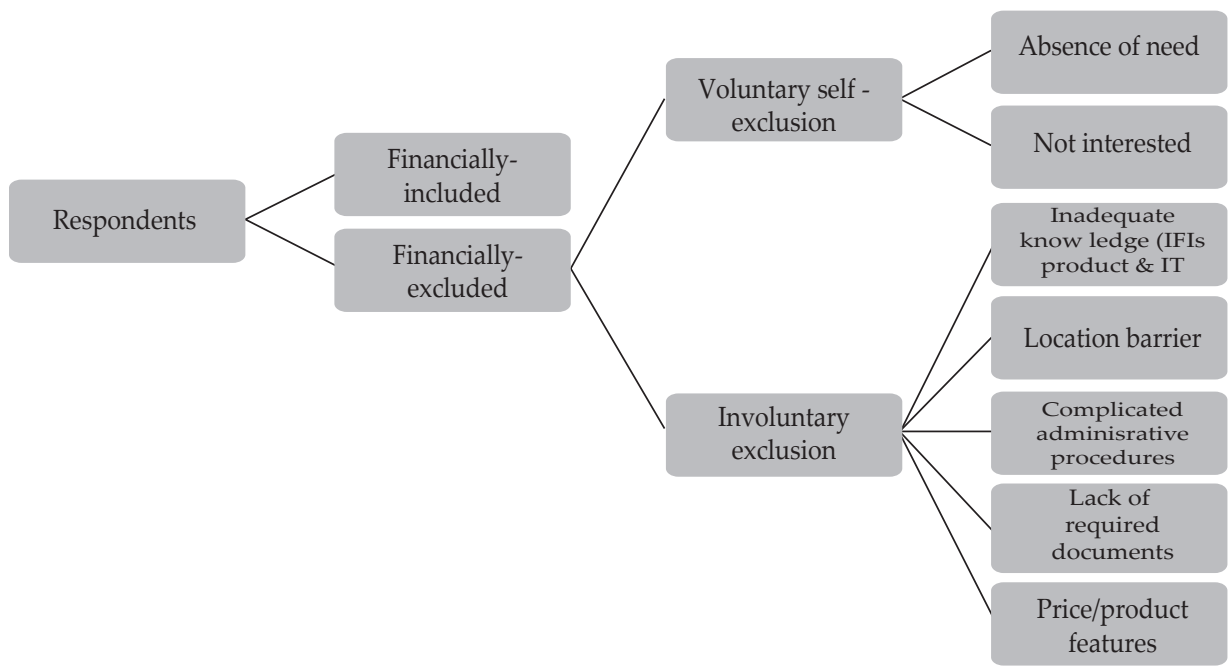




\subsubsection{Determinants of Islamic Financial Exclusion in Indonesia}

The determinants of Islamic financial exclusion are presented in two stages: the measurement model of the $1^{\text {st }} \mathrm{CFA}$ and the measurement model of the $2^{\text {nd }} \mathrm{CFA}$. Table 4.2 provides $1^{\text {st }}$ CFA measurements for demand factors, which are comprised of four latent variables with six indicators in each variable except for socioeconomic factors. Within the socioeconomic variables, out of 9 (nine) indicators, only 3 (three) are significant, valid, and reliable in explaining socioeconomic variables. Nevertheless, the relationship between valid indicators and their latent variables is negative. Therefore, socioeconomic latent variables are excluded from the analysis.

Under financial literacy, all indicators can significantly explain financial literacy. The finding indicates that financial behaviour takes the highest indicator at 0.82 , followed by financial self-efficacy (0.70), financial technology awareness (0.69), use of media (0.43), financial knowledge (0.40), and financial education (0.36), respectively.

Table 4.2 also provides findings related to religious commitment, in which all indicators significantly explain the latent variable, apart from the commitment to Islamic financial institutions and religious affiliation. This is understood since respondents, who are financially-excluded, are expected to be less committed to Islamic financial products and services. Nevertheless, a standardised solution provides information on the rank of indicators, in which fears of punishment are the highest indicator for explaining religious commitment at 0.98 , followed by commitment to worship (0.93), interest perception (0.73), and barriers to interest (0.32). The last variable of the demand factors is social influence, which suggests that all indicators are significant for explaining latent variables. The findings indicate that community influence takes the highest place among other variables at 0.89 , followed by informal leader influence $(0.85)$, culture influence $(0.80)$, friend and colleague influence (0.69), family influence (0.68), and media influence (0.64), respectively.

A measurement model for all latent variables from the demand factors satisfies two main conditions, namely positive degree of freedom (315), and RMSEA $\leq$ 0.08 (0.055). All goodness of fit (GoF) measures fit; thus, we can conclude that the measurement model of financial literacy, religious commitment, and social influence is a good fit. 
Table 4.2.

$1^{\text {st }}$ CFA Measurement Model of Demand Factors

\begin{tabular}{|c|c|c|c|c|}
\hline Variables & Indicators & t-value & $\begin{array}{l}\text { Standardised } \\
\text { Solution }\end{array}$ & Explanation \\
\hline \multirow[t]{9}{*}{ Socioeconomic } & Gender & 0.65 & 0.06 & Invalid \\
\hline & Age & 1.21 & 0.08 & Invalid \\
\hline & Living area & 1.29 & 0.10 & Invalid \\
\hline & Job & -2.03 & -1.17 & Valid \\
\hline & Education & -1.71 & -0.20 & Invalid \\
\hline & Marital status & 1.71 & 0.15 & Invalid \\
\hline & Income & -2.57 & -1.56 & Valid \\
\hline & House type & -1.21 & -0.08 & Invalid \\
\hline & Electricity usage & -2.30 & -0.06 & Valid \\
\hline \multirow[t]{6}{*}{ Financial Literacy } & Financial knowledge & 3.78 & 0.40 & Valid \\
\hline & Financial education & 3.21 & 0.36 & Valid \\
\hline & Financial behaviour & 6.67 & 0.82 & Valid \\
\hline & Fintech awareness & 6.15 & 0.69 & Valid \\
\hline & Financial self-efficacy & 6.42 & 0.70 & Valid \\
\hline & Use of media & 4.05 & 0.43 & Valid \\
\hline \multirow[t]{6}{*}{ Religious Commitment } & Commit to worship & 12.41 & 0.93 & Valid \\
\hline & Fears of punishment & 13.35 & 0.98 & Valid \\
\hline & Interest perception & 7.80 & 0.73 & Valid \\
\hline & Barriers to interest & 2.23 & 0.32 & Valid \\
\hline & Commit to IFIs & 1.76 & 0.24 & Invalid \\
\hline & Religious affiliation & 1.76 & 0.24 & Invalid \\
\hline \multirow[t]{6}{*}{ Social influence } & Family influence & 7.12 & 0.68 & Valid \\
\hline & Friend \& Colleague influence & 7.63 & 0.69 & Valid \\
\hline & Media influence & 7.25 & 0.64 & Valid \\
\hline & Informal leader influence & 8.54 & 0.85 & Valid \\
\hline & Community influence & 9.46 & 0.89 & Valid \\
\hline & Culture influence & 8.28 & 0.80 & Valid \\
\hline \multicolumn{5}{|c|}{ Goodness of fit test } \\
\hline
\end{tabular}

Table 4.3 provides the $1^{\text {st }}$ CFA measurement from the supply factors, which comprises four latent variables with six indicators in each variable. In contrast to the previous result, all latent variables in supply factors imply significant indicators in explaining infrastructure, products and services, human capital, and policies and regulations. According to the infrastructure variables, the finding indicates that network connectivity and financial technology readiness are the highest ranks among the other variables at 0.86 , followed by mobile infrastructure (0.72), distribution channel (0.63), location (0.55), and distance (0.40), respectively. Regarding the products and services variable, collateral represents the highest indicator to explain its latent variables at 0.84 , followed by transaction costs $(0.78)$, safety (0.77), transparency (0.70), product fit (0.68), and document requirements (0.53), respectively. 
Furthermore, KPI targeting registers the highest indicator when explaining human capital factors at 0.89 , followed by social awareness (0.88), employee background (0.77), understanding and knowledge (0.75), risk-taking behaviour (0.70), and educational background (0.59), respectively. Finally, regarding the policy and regulation latent variable, financial technology regulation is the most significant indicator in explaining its latent variable at 0.96 , followed by consumer protection (0.92), distribution policy (0.90), literacy regulation (0.74), data infrastructure (0.71), and incentives (0.69), respectively.

The measurement model for all latent variables from supply factors satisfies the two main conditions: a positive degree of freedom (327.89), and RMSEA $\leq 0.08$ (0.063). All GoF measures fit, therefore, we can conclude that the measurement model of infrastructure, products and services, human capital, and policy and regulation is a good fit.

Table 4.3.

$1^{\text {st }}$ CFA Measurement Model of Supply Factors

\begin{tabular}{|c|c|c|c|c|}
\hline Variables & Indicators & t-value & $\begin{array}{l}\text { Standardised } \\
\text { Solution }\end{array}$ & Explanation \\
\hline \multirow[t]{6}{*}{ Infrastructure } & Location & 5.51 & 0.55 & Valid \\
\hline & Distance & 4.13 & 0.40 & Valid \\
\hline & Distribution channel & 6.87 & 0.63 & Valid \\
\hline & Mobile infrastructure & 8.36 & 0.72 & Valid \\
\hline & Network connectivity & 9.72 & 0.86 & Valid \\
\hline & Fintech readiness & 9.50 & 0.86 & Valid \\
\hline \multirow[t]{6}{*}{ Product and Services } & Product fit & 7.07 & 0.68 & Valid \\
\hline & Transparency & 7.42 & 0.70 & Valid \\
\hline & Safety & 8.31 & 0.77 & Valid \\
\hline & Transaction cost & 8.56 & 0.78 & Valid \\
\hline & Document requirements & 6.44 & 0.53 & Valid \\
\hline & Collateral & 9.04 & 0.84 & Valid \\
\hline \multirow[t]{6}{*}{ Human Capital } & Educational background & 5.66 & 0.59 & Valid \\
\hline & Understanding \& knowledge & 7.80 & 0.75 & Valid \\
\hline & Social awareness & 9.59 & 0.88 & Valid \\
\hline & Employee background & 8.21 & 0.77 & Valid \\
\hline & KPI targeting & 10.13 & 0.89 & Valid \\
\hline & Risk taking behaviour & 7.20 & 0.70 & Valid \\
\hline \multirow[t]{6}{*}{ Policy \& Regulation } & Literacy regulation & 7.22 & 0.74 & Valid \\
\hline & Incentives & 7.75 & 0.69 & Valid \\
\hline & Fintech regulation & 12.10 & 0.96 & Valid \\
\hline & Consumer protection & 11.16 & 0.92 & Valid \\
\hline & Distribution policy & 10.45 & 0.90 & Valid \\
\hline & Data infrastructure & 8.28 & 0.71 & Valid \\
\hline \multicolumn{5}{|c|}{$\begin{array}{c}\text { Goodness of fit test } \\
\text { Chi-Square }=327.89, \mathrm{df}=222, \mathrm{p} \text {-value }=0.0000, \text { RMSEA }=0.063\end{array}$} \\
\hline
\end{tabular}


Following the detailed results from the $1^{\text {st }}$ CFA measurement model, the findings of the $2^{\text {nd }}$ CFA measurement model are exhibited in Figure 4.5. The $2^{\text {nd }}$ CFA measurement explains the Islamic financial exclusion model using seven (7) indicators: financial literacy (FL), religious commitment (RC), social influence (SI), infrastructure (I), products and services (PS), human capital (HC), and policies and regulations (PR). The $2^{\text {nd }} C F A$ model of latent variables of Financial Exclusion (FINEX) satisfies four main conditions: RMSEA $\leq 0.08$ (0.051), NFI $\geq 0.9$ (0.98), IFI $\geq 0.9$ (1.00), NNFI $\geq 0.9$ (0.99), RFI $\geq 0.9$ (0.95), and P-Value $\geq 0.050$ (0.26921), while other variables such as PNFI $\geq 0.9$ (0.37) indicate a marginal fit. According to the GoF measurement, we can conclude that the $2^{\text {nd }} \mathrm{CFA}$ measurement model of financial exclusion is a good fit. All indicators (FL, RC, SI, I PS, HC, and PR) are significant, valid, and reliable in explaining Islamic financial exclusion in Indonesia. Nevertheless, a socioeconomic latent variable has been excluded from the model due to its insignificant value for the $2^{\text {nd }}$ CFA model. Based on the coefficient values, human capital is the highest indicator in explaining Islamic financial exclusion in Indonesia at 0.89 , while products and services are the secondhighest indicator at 0.88 , followed by infrastructure $(0.82)$, policies and regulations (0.79), financial literacy (0.56), social influence $(0.44)$, and religious commitment (0.32), respectively.

Figure 4.5.

$2^{\text {nd }}$ CFA Measurement Model of Islamic Financial Exclusion in Indonesia t-value Standardised Solution
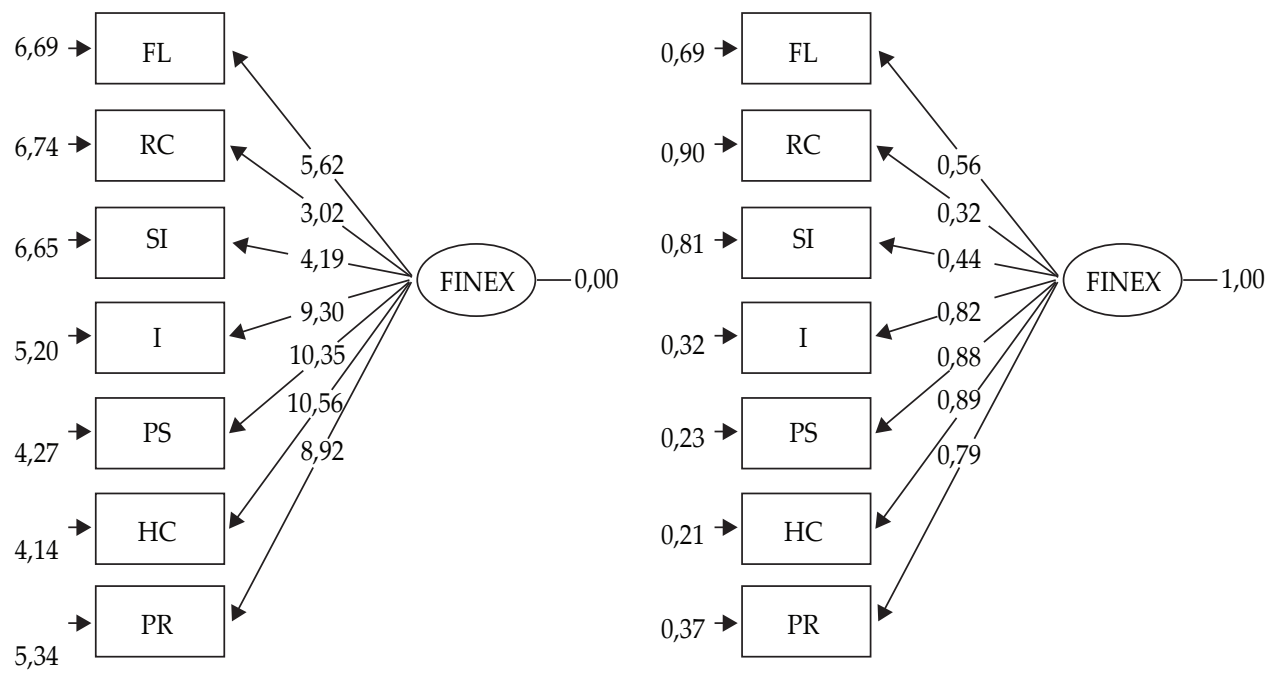

Chi-Square $=9.94, \mathrm{df}=8, \mathrm{p}$-value $=0.26921, \mathrm{RMSEA}=0.051$

$\mathrm{NFI}=0.98, \mathrm{IFI}=1.00, \mathrm{NNFI}=0.99, \mathrm{PNFI}=0.37, \mathrm{RFI}=0.95$ 


\subsection{Analysis}

The findings of this study are consistent with some previous studies in terms of financial exclusion and financial inclusion. For example, regarding the financial literacy latent variables, it was determined that financial behaviour is the highest indicator. Murata and Hori (2006) examined depositor behaviour by observing deposit shifting patterns among small Japanese banking institutions in the 1990s. Their findings indicate that most depositors are sensitive to bank risks. Riskier institutions attract smaller deposits because depositors tend to search for less risky financial institutions. In this regard, IFIs are considered riskier than conventional ones due to the concept of profit and loss sharing embedded in the IFIs. Cubillas et al. (2015) also addressed depositors' behaviour; they discover that they practically penalise riskier banks by demanding higher interest rates on deposits or by withdrawing their deposits.

Regarding the religious commitment latent variables, this study reveals that fears of punishment are the highest indicator in explaining religious commitment. This finding confirms those of previous studies (Gerrans et al., 2009; Hassan et al., 2019; Khan, 2010; Zulkhibri, 2016) in that 'faith premiums' affect financial decisions. Nevertheless, due to a lack of knowledge and awareness (Dupas \& Robinson, 2012; Ellis, Lemma \& Rud, 2010), there is a misconception among those in the low-income segment that participating in formal institutions has no religious implications. The finding also indicates that commitment to Islamic financial institutions and religious affiliations do not significantly explain religious commitment. This is, perhaps, because respondents are financially-excluded and, therefore, are less committed to Islamic financial products and services.

Regarding the social influence variables, the study discovered that community influence takes the highest priority. This finding confirms those of previous studies (Zhu et al., 2012) in that participation within a community increases people's riskseeking tendencies in their financial decisions and behaviours. The authors also discover a boundary condition to that effect, in which the community will only have a strong influence if they have relatively strong ties with other members. Otherwise, they exhibit similar preferences as non-members.

Moving to supply factors, the highest indicators of infrastructure latent variables are network connectivity and readiness for financial technology. This finding supports the study by Hamzah et al. (2013), who suggest that a lack of network connectivity and cooperation are the most critical barriers to Islamic finance development in Indonesia. This is understood because rational customers tend to choose financial institutions that offer easy access and efficient procedures, which can be partly achieved through fintech.

Regarding the products and services variable, collateral is the highest indicator for explaining latent variables. In most of the literature, collateral is recognised as an essential determinant of financial exclusion (Allen et al., 2014; Beck et al., 2008). Furthermore, KPI targeting is the highest indicator in explaining human capital factors. This finding confirms those of previous studies (Loo, 2009; Buchari et al., 2015) who argue that KPIs are an essential component of evaluating the competitiveness of IFI employees. Finally, based on policy and regulation latent variables, financial technology regulations indicate the most significant indicator. Buckley and Webster (2016) highlight that customers can choose and fulfil their 
desired wants and urgent needs. Mohamed and Ali (2018) echo the view that digital transformation is one way to change customers' unpredictable behaviours. The influence of digitalisation in customers' lives and in psychology is vital for all industries, especially the financial services industry.

'The digital transformation shift also has changed the expectations and wants of the customers. Today, customers want banking (or any other service) from anywhere they are and at any time, regardless of if they are in the office, or at home in the evenings, or at a beach or in the park at the weekend. This digital behaviour of customers has set a new bar for different services industries. The industry is trying to fulfil the needs of these digital mindsets by using Omni channels and advanced technologies. The competition among financial institutions and fintech platform to provide more customer-centric services is increasing' (Dharmesh, 2016).

Regarding the $2^{\text {nd }}$ CFA model of latent variables of Islamic Financial Exclusion (FINEX), human capital records the highest indicator in explaining this in the context of Indonesia, while products and services are the second priority, followed by infrastructure, policies and regulations, financial literacy, social influence, and religious commitment. This finding is consistent with that of previous studies. For example, Bontis (1998) concludes that human capital is an integral part of structural capital, which creates, acquires, and employs consumer capital to achieve organisational objectives. In contrast, weak human capital and high financial illiteracy might prevent a large number of populations from participating in financial products and services (Arora, 2012). Ellis, Lemma and Rud (2010) also affirm that human capital significantly contributes to the broader access of financial products and services, image, and delivery services. The World Bank Group (2012) state that financial institutions must improve their ability to deliver products and services to meet the needs of different clientele, their demography, and their financial conditions to strengthen their role in financial inclusion.

\section{CONCLUSION AND RECOMMENDATION}

\subsection{Conclusion}

The study has presented barriers facing financially-excluded respondents in accessing IFI products and services. The study discovered that prominent barriers to obtaining financing products in IFIs include location, complicated administration procedures, lack of proper financial reports, lack of required documentation, and expensive administrative costs. Meanwhile, the barriers to opening savings accounts in IFIs involve the location of Islamic banks/Islamic microfinance, complicated administration procedures, lack of required documents, lack of trust in IFIs, and expensive administrative costs. Other factors include: i) they have a joint account with their spouse; ii) they have a conventional account; iii) there is a lack of information about Islamic financial products and services; and iv) the technology is less competitive.

As for barriers to financial access in the Islamic capital market, the study cited the following: a lack of knowledge about Islamic capital market, a lack of information about Islamic capital market products, a lack of knowledge on about technology in the Islamic capital market, an absence of interest in investment, high risk, distance from the agent's location, unaffordable minimum investment 
placements, complicated administration procedures, lack of trust in the agent, absence of required documents, expensive brokerage fees, and high costs of opening an account.

This paper also investigated valid indicators for the construction of an Islamic financial exclusion model and its determinants in Indonesia. The study discovered that human capital was the highest indicator for explaining Islamic financial exclusion in Indonesia, followed by products and services, infrastructure readiness, policies and regulations, financial literacy, social influence, and religious commitment, respectively.

With particular reference to the indicators for each variable, financial behaviour was the highest indicator for explaining financial literacy, while financial education was the model's lowest priority. Fears of punishment are the most significant indicator for describing religious commitment, while barriers to interest is the model's lowest priority. Regarding the social influence variable, community influence is the highest priority among the indicators and media influence is the model's lowest priority. Regarding the infrastructure latent variables, both network connectivity and financial technology readiness represent the highest priority among the indicators, while distance from financial services remained the lowest priority. Collateral was the most critical indicator in explaining products and services and document requirements were the lowest priority. KPI targeting signified the most significant indicator for explaining human capital and educational background was deemed to be the least significant. Finally, under the policy and regulation variable, fintech regulations was the highest significance indicator and incentives was the least significant.

\subsection{Recommendation}

\subsubsection{Implications for Islamic Financial Institutions}

Based on the various findings on the barriers to financial access and the determinants of Islamic financial exclusion, this study recommends the following:

1. IFIs should improve their infrastructure readiness by: (i) opening more branches and services agents; and (ii) leveraging on financial technology and network connectivity.

2. IFIs should strengthen their human capital competencies and skills via training and education, capacity building, social awareness programmes, and risk culture creation programmes.

3. IFIs should develop a more structured methodology and approach toward awareness of Islamic financial product and services by introducing sustainable community-based education programmes for financially-excluded respondents.

\subsubsection{Implications for Financial Regulators}

The government should play an active role in enhancing Islamic financial literacy, particularly for financially-excluded people. In this regard, it is imperative that the government sets the appropriate focus and theme through the introduction of an Islamic financial literacy programme. The focus of the financial literacy 
agenda should revolve around the following aspects: the understanding of Islamic financial products and services, the integral position of Islamic finance in Islamic teachings, the prohibition of riba in conventional finance and its divine punishments, the security aspects of Islamic financial products and services, and the integration of fintech in Islamic financial product and services. In addition, the government should outline a conducive and supportive fintech regulation to facilitate broader and easier access to Islamic financial products and services.

\subsubsection{Recommendation for Future Research}

Future research should consider the low, medium, and high financial inclusion in its sampling selection. Further empirical research is suggested with the addition of more latent variables and the gathering of more representative respondents. The use of other enhanced analytical tools such as Partial Least Square (PLS) and Structural Equation Modelling (SEM) is also recommended to find the interrelationships between latent variables.

Acknowledgement: This research is funded by the Central Bank of Indonesia under the Research Grant Bank Indonesia Programme 2018. The authors would like to thank Dr M Rizky Prima Sakti and Witri Aulia Maudy for their assistance in this project.

\section{REFERENCES}

Aduda, J. \& Kalunda, E. (2012). Financial Inclusion and Financial Sector Stability with Reference to Kenya: A Review of Literature. Journal of Applied Finance and Banking, 2(6), 95-120.

Ali, M.M. (2018). Islamic Finance Promotes Inclusion. https://www.nst.com.my/ opinion/columnists/2018/10/422674/islamic-finance-promotes-inclusion. Retrieved 10 Dec 2018.

Allen, F., Demirguc-Kunt, A., Klapper, L, \& Peria (2012). The Foundations of Financial Inclusion: Understanding Ownership and Use of Formal Accounts. Policy Research Working Paper 6290. The World Bank Development Research Group Finance and Private Sector Development Team.

Anderson, J. C. \& Gerbing, D. W. (1984). The Effect of Sampling Error on Convergence, Improper Solutions, and Goodness-of-fit indices for Maximum Likelihood Confirmatory Factor Analysis. Psychometrika, 49(2), 155-173.

Arora, R. U. (2012). Financial Inclusion and Human Capital in Developing Asia: The Australian connection. Third World Quarterly, 33(1), 177-197.

Ascarya, H . \& Rahmawati, S. (2018). Analysis of the Determinants of Micro Enterprises Graduation. Journal of Islamic Economics, Banking and Finance, 14(1), $1-52$.

Beck, T., Kunt, A.D., and Peria, M.S.M. (2008). Banking Services for Everyone? Barriers to Bank Access and Use around the World. The World Bank Economic Review, 22(3), 397-430.

Bontis, N. (1998). Intellectual Capital: An Exploratory Study that Develops Measures and Models. Management decision, 36(2), 63-76. 
Brown, T. A. (2006). Confirmatory Factor Analysis for Applied Research. New York, London: The Guilford Press.

Buchari, I., Rafiki, A., \& Al Qassab, M. A. H. (2015). Awareness and Attitudes of Employees towards Islamic Banking Products in Bahrain. Procedia Economics and Finance, 30, 68-78.

Buckley, R. P. \& Webster, S. (2016). Fintech in Developing Countries: Charting New Customer Journeys. Journal of Financial Transformation, 44.

Carbo, S., Gardener, E. P., \& Molyneux, P. (2005). Financial Exclusion in Europe. In Financial Exclusion (pp. 98-111). Palgrave Macmillan, London.

Choudhury, M. Alam. (2001). Financial Globalization and Islamic Financing Institutions: The Topic Revisited. Islamic Economi Studies, 9(1), 19-38.

Collard, S., Kempson, E., \& Whyley, C. (2001). Tackling financial exclusion. Policy.

Cubillas, E., Fernadez, A.I., Gonzalez, F. (2015). How credible Is a Too-Big-To-Fail Policy? International Evidence From Market Discipline. J. Financ. Intermed.

Demirgüç-Kunt, A. \& Klapper, L. (2013). Measuring Financial Inclusion: Explaining Variation in Use of Financial Services Across and within Countries. Brookings Papers on Economic Activity, 1, 279-340.

Dupas, P. \& Robinson, J. (2012). The (hidden) Costs of Political Instability: Evidence from Kenya's 2007 Election Crisis. Journal of Development Economics, 99(2), 314-329.

Ellis, K., Lemma, A., \& Rud, J. P. (2010). Financial Inclusion, Household Investment and Growth in Kenya and Tanzania. Overseas Development Institute. Project Briefing No, 43, 2010.

Gerrans, P., Clark-Murphy, M., \& Truscott, K. (2009). Financial Literacy and Superannuation Awareness of Indigenous Australians: Pilot Study Results. Australian Journal of Social Issues, 44(4), 417-439

Hassan, Hossain, \& Unsal. (2019) 'Religious Preference and Financial Inclusion: The Case for Islamic Finance' In Management of Islamic Finance: Principle, Practice, and Performance.

Howell, N. (2005). Financial exclusion And Microfinance: An Overview of the Issues. Opportunity Knocks: Microfinance as a Pathway to Financial and Social Exclusion, 27, 2.

International Monetary Fund Press Release No 18/193 'IMF Executive Board Adopts Decisions to Formally Recognize the Core Principles for Islamic Finance Regulation (CPIFR) for Banking. HYPERLINK "http://www.imf.org" www.imf.org

Iqbal, Z. (2014). Enhancing Financial Inclusion through Islamic Finance. In Financial Inclusion Conference, Turkey.

Iqbal, Z., \& Mirakhor, A. (Eds.). (2013). Economic Development and Islamic Finance. The World Bank.

Islam, Md. Ezazul. (2016). Financial Inclusion in Asia and the Pacific. Thailand: Macroeconomic Policy and Financing for Development Division (MPFD).

Jouti, A.T. (2018). Islamic Finance: Financial Inclusion or Migration? ISRA International Journal of Islamic Finance, 10(2), 277-288.

Kelly, S., Ferenzy, D., \& McGrath, A. (2017). How Financial Institutions and Fintechs are Partnering for Inclusion: Lessons From The Frontlines. A Joint Report From The Center for Financial Inclusion at Accion and The Institute of International Finance. 
Kempson, E. \& Whyley, C. (1999). Understanding and Combating Financial Exclusion. Insurance Trends, 21(1), 18-22.

Khan, F. (2010). How 'Islamic' is Islamic banking? Journal of Economic Behavior $\mathcal{E}$ Organization, 76(3), 805-820.

Kimutai, B. J. (2015). Factors Influencing Financial Inclusion in Rural Kenya: A Case Study of Kenya Commercial Bank Agent Outlets in Marakwet West Sub County. Unpublished Ph. D., Thesis, University of Nairobi, Department of Extra Mural Studies, Nairobi, 1-8.

Kostov, P., Arun, T, \& Annim, A. (2015). Access to Financial Services: The Case of the 'Mzansi' Account in South Africa. Review of Development Finance, 5, 34-42. Leyshon, A. \& Thrift, N. (1995). Geographies of financial exclusion: financial abandonment in Britain and the United States. Transactions of the Institute of British Geographers, 312-341.

Loo, M. (2009). Attitudes and Perceptions towards Islamic Banking among Muslims and non-Muslims in Malaysia: Implications for Marketing to Baby Boomers and X-Generation. International Journal of Arts and Sciences, 3(13), 453-485.

McKillop, D. \& Wilson, J. (2007). Financial exclusion. Public Money and Management, 27(1), 9-12.

Mohamed, H. \& Ali, H. (2018). Blockchain, Fintech, and Islamic Finance: Building the Future in the New Islamic Digital Economy. Walter de Gruyter GmbH \& Co KG.

Mohieldin, M., Iqbal, Z., Rostom, A., \& Fu, X. (2011). The Role of Islamic Finance in Enhancing Financial Inclusion in Organization of Islamic Cooperation (OIC) Countries. Policy Research Working Paper 5920. The World Bank Development Research Group. Finance and Private Sector Development Team, December 2011.

Murata, K. \& Hori, M. (2006). Do Small Depositors Exit from Bad Banks? Evidence from Small Financial Institutions in Japan. The Japanese Economic Review, 57(2), 260-278.

Mylonidis, N., Chletsos, M., \& Barbagianni, V. (2017). Financial Exclusion in the USA: Looking beyond Demographics. Journal of Financial Stability .

Naceur, S.B., Barajas, A., \& Massara, A. (2015). Can Islamic Banking Increase Financial Inclusion? IMF Working Paper WP/15/31, February 2015.

Namasivayam, K. \& Denizci, B. (2006). Human Capital in Service Organizations: Identifying Value Drivers. Journal of Intellectual Capital, 7(3), 381-393.

Obaidullah, M. \& Latiff, H. S. H. A. (2008). Islamic Finance for Micro and Medium Enterprises. Islamic Research \& Training Institute Islamic Development Bank, Centre for Islamic Banking, Finance and Management Universiti Brunei Darussalam.

Rosengard, J. K. \& Prasetyantoko, A. (2011). If the banks are doing so well, why can't I get a loan? Regulatory Constraints to Financial Inclusion in Indonesia. Asian Economic Policy Review, 6(2), 273-296.

Rusby, Z. \& Hamzah, Z. (2013). Analysis problem of Baitul Maal Wat Tamwil (BMT) Operation in Pekanbaru Indonesia using Analytical Network Process (ANP) Approach. International Journal of Academic Research in Business and Social Sciences, 3(8), 215.

Sain, M. R. M., Rahman, M. M., \& Khanam, R. (2016). Financial Exclusion in Australia: Can Islamic Finance Minimise the Problem? Australasian Accounting, Business and Finance Journal, 10(3), 89-104. 
Schumacker, R. E., \& Lomax, R. G. (1996). A Beginner's Guide to Structural Equation Modeling. Mahwah, NJ: L. L. Erlbaum Associates.

Sideridis, G., Simos, P., Papanicolaou, A., \& Fletcher, J. (2014). Using Structural Equation Modelling to Assess Functional Connectivity in the Brain Power and Sample Size Considerations. Educational and Psychological Measurement, 74(5), 733-758.

Simpson, W. \& Buckland, J. (2009). Examining Evidence of Financial and Credit Exclusion in Canada from 1999 to 2005. The Journal of Socio-Economics, 38(6), 966-976.

Sinclair, S. P. (2001). Financial Exclusion: An Introductory Survey. CRSIS, Edinburgh College of Art/Heriot Watt University.

Suhr, D. D. (2006). Exploratory or Confirmatory Factor Analysis?

Umar, A.I. (2017). Index of Syariah Financial Inclusion in Indonesia. Buletin Ekonomi Moneter dan Perbankan, 20(1), 99-126.

Warsame, M. (2009). The Role of Islamic Finance in Tackling Financial Exclusion in the UK (Doctoral dissertation, Durham University).

Wolf, E. J., Harrington, K.M., Clark, S.L., \& Miller, M.W. (2013). Sample Size Requirements for Structural Equation Models an Evaluation of Power, Bias, and Solution Propriety. Educational and Psychological Measurement, 73(6), 913934.

World Bank Group. (2012). Financial Inclusion Strategies Reference Framework. Prepared by the World Bank for the G20 Mexico Presidency.

World Bank. (2014). Global Financial Development Report: Financial Inclusion. Washington, D.C: The World Bank.

Zhu, R., Dholakia, U. M., Chen, X., \& Algesheimer, R. (2012). Does Online Community Participation Foster Risky Financial Behavior? Journal of Marketing Research, 49(3), 394-407.

Zins, A. \& Weill, L. (2016). The Determinants of Financial Inclusion in Africa. Review of Development Finance, 6, 46-57.

Zulkhibri, M. (2016). Financial Inclusion, Financial Inclusion Policy and Islamic Finance. Macroeconomics and Finance in Emerging Market Economies, 9(3), 303320. 
This page is intentionally left blank 